\title{
Wpływ mikrostarterów B i K na wielkość i jakość bulw ziemniaka
}

\author{
The influence of microstarters $\mathrm{B}$ and $\mathrm{K}$ on the volume and quality of potato tubers
}

Jerzy Osowski ${ }^{1 \oplus}$, Janusz Urbanowicz ${ }^{2 \oplus}$

Instytut Hodowli i Aklimatyzacji Roślin - PIB w Radzikowie, Oddział w Boninie, 76-009 Bonin 3

$\triangle$ e-mail: j.osowski@ihar.edu.pl

W latach 2016-2018 w Oddziale IHAR-PIB w Boninie oceniano wpływ zastosowania nawozów mikroelementowych Micro $1 \mathrm{~B}$ i Mikro $1 \mathrm{~K}$ jako nawożenie uzupełniające nawożenie podstawowe pod ziemniaki. Największy plon bulw uzyskano dla kombinacji, w której do nawożenia podstawowego zastosowano dodatkowo nawóz Micro $1 \mathrm{~K}$. Na poletkach, na których aplikowano ten zestaw nawozów stwierdzono najwyższy wzrost plonu ogólnego, oraz plonu bulw dużych (powyżej $55 \mathrm{~mm}$ ), przydatnych do przetwórstwa. Stwierdzono także korzystny wpływ mikrostartera Mikro $1 \mathrm{~B}$ na zawartość skrobi w bulwach.

\section{Słowa kluczowe: ciemnienie bulw, Micro 1 B, Micro 1 K, nawozy, plon, skrobia}

In the years 2016-2018, the IHAR-PIB Branch in Bonin assessed the effect of the application of micro 1 B and Micro $1 \mathrm{~K}$ micronutrient fertilizers as supplementary fertilization for basic fertilization for potatoes. The highest tuber yield was obtained for the combination in which the basic fertilization was additionally applied with Micro1K. In the plots where this set of fertilizers was applied, the highest increase in the total yield, and the yield of large tubers (over $55 \mathrm{~mm}$ ) suitable for processing was observed. The beneficial effect of the Micro $1 \mathrm{~B}$ on the starch content in tubers was also found.

Key words: darkening of tubers, fertilizers, Micro $1 \mathrm{~B}$, Micro $1 \mathrm{~K}$, starch, yield

\begin{abstract}
Wstęp
Rośliny uprawne, $\mathrm{w}$ tym również ziemniak potrzebują do prawidłowego rozwoju i kształtowania plonu zarówno makro- i mikroelementów, które odpowiadają w roślinie za konkretne funkcje. Niedobór składników pokarmowych może powodować hamowanie rozwoju i spowalnianie procesów życiowych, co w konsekwencji negatywnie wpływa na wielkość i jakość plonu bulw (Stępień i in. 2009). Jednym z głównych zabiegów agrotechnicznych istotnie wpływających na wielkość uzyskiwanego plonu oraz jakość bulw potomnych jest nawożenie (Szewczuk, 2009; Trawczyński, Prokop 2016). Ziemniaki ze względu na długi okres wegetacji (odmiany późne powyżej $130 \mathrm{dni}$ ) oraz dużą masę plonu wymagają dobrego zaopatrzenia w składniki pokarmowe przez cały okres wegetacji. Kompleksowe dostarczenie łatwo dostępnych składników pokarmowych istotnie wpływa na przebieg procesów fizjologicznych, rozwój roślin oraz zawiązywanie i rozwój bulw potomnych (Grzyś, 2004; Zarzecka, 2006). Efektywność zastosowanego nawożenia zależy między innymi od warunków glebowych
\end{abstract}

(kategorii agronomicznej, zawartości próchnicy, składników pokarmowych, odczynu), wilgotnościowo-termicznych w okresie wegetacji (opadów, temperatury powietrza) oraz rodzaju zastosowanych nawozów. Jednym z takich rozwiązań jest stosowanie nawozów specjalistycznych, tak doglebowych, jak i dolistnych (Trawczyński, Prokop, 2016). Nawozy takie zawierają w swoim składzie między innymi mikroelementy, które występują w enzymach spełniając rolę katalizatorów i regulując procesy biochemiczne (Grzyś, 2004). Niedobór mikroelementów wpływa zasadniczo na cechy jakościowe plonu oraz radykalnie obniża ich wielkość (Czuba, 2000). Rola i znaczenie mikroelementów ulega znacznemu wzrostowi w ostatnich latach, co związane jest z wprowadzaniem coraz bardziej intensywnych i plennych odmian roślin, u których wzrost poziomu plonowania wpływa na zwiększone zapotrzebowanie roślin na mikroelementy, wzrostem udziału gleb o niskiej zawartości przyswajalnych mikroelementów oraz zbyt niskiej ich zawartości w roślinach, zwłaszcza $\mathrm{z}$ punktu widzenia wartości konsumpcyjnej i paszowej (Grzyś, 2004; 
Brown, 2004; Imas, Magen, 2004).

Celem pracy było sprawdzenie wpływu zastosowania nawozów specjalistycznych Micro 1 B i Micro $1 \mathrm{~K}$, zawierających mikroelementy Mn i Zn schelatowane przez EDTA, na rozwój roślin oraz na wielkość i jakość plonu bulw.

\section{Material i Metody}

Doświadczenia polowe przeprowadzono w Oddziale IHAR-PIB w Boninie k/Koszalina (województwo zachodniopomorskie) w latach 2016-2018. Efekty doglebowej aplikacji nawozów Micro $1 \mathrm{~B}$ i Micro $1 \mathrm{~K}$ określano na średnio późnej jadalnej odmianie Jelly. Badania obejmowały następujące kombinacje:

- MB-1 - nawożenie nawozem Micro 1 B w dawce $25 \mathrm{~kg} \cdot \mathrm{ha}^{-1}\left(\mathrm{Mg}-4,0 \mathrm{~kg} \cdot \mathrm{ha}^{-1}, \mathrm{SO}_{3}-\right.$ $8,25 \mathrm{~kg} \cdot \mathrm{ha}^{-1}, \mathrm{~B}-22,5 \mathrm{~g} \cdot \mathrm{ha}^{-1}$, Mo - 2,5 $\mathrm{g} \cdot \mathrm{ha}^{-1}$, $\left.\mathrm{Mn}-250 \mathrm{~g} \cdot \mathrm{ha}^{-1}, \mathrm{Zn}-750 \mathrm{~g} \cdot \mathrm{ha}^{-1}\right)$;
- MK-1 - nawożenie nawozem Micro $1 \mathrm{~K}$ w dawce $25 \mathrm{~kg} \cdot \mathrm{ha}^{-1}\left(\mathrm{NH}_{4}-1 \mathrm{~kg} \cdot \mathrm{ha}^{-1}, \mathrm{P}_{2} \mathrm{O}_{5}-\right.$ 7,5 kg $\cdot \mathrm{ha}^{-1}, \mathrm{~K}_{2} \mathrm{O}-5,0 \mathrm{~kg} \cdot \mathrm{ha}^{-1}, \mathrm{SO}_{3}-2,8 \mathrm{~g} \cdot \mathrm{ha}^{-1}$, $\left.\mathrm{Mn}-100 \mathrm{~g} \cdot \mathrm{ha}^{-1}, \mathrm{Zn}-500 \mathrm{~g} \cdot \mathrm{ha}^{-1}\right)$;

- NM - nawożenie mineralne nawozem Yara Mila 14-14-21 w dawce $700 \mathrm{~kg} \cdot \mathrm{ha}^{-1}(98-\mathrm{kg}$ $\left.\mathrm{N} \cdot \mathrm{ha}^{-1}, 98 \mathrm{~kg}-\mathrm{P}_{2} \mathrm{O}_{5} \cdot \mathrm{ha}^{-1}, 147 \mathrm{~kg}-\mathrm{K}_{2} \mathrm{O} \cdot \mathrm{ha}^{-1}\right)$;

- NM + MB-1 - nawożenie nawozem Yara Mila 14-14-21 (700 kg ha $\left.{ }^{-1}\right)+$ MB-1 (25 kg $\left.\cdot \mathrm{ha}^{-1}\right)$;

- NM + MB-1 - nawożenie nawozem Yara Mila 14-14-21 (700 kg ha $\left.{ }^{-1}\right)+$ MK-1 $\left(25 \mathrm{~kg} \cdot \mathrm{ha}^{-1}\right)$.

Doświadczenia polowe o powierzchni poletka wynoszącej 22,5 $\mathrm{m}^{2}$ (100 roślin) w czterech powtórzeniach założono $\mathrm{w}$ układzie losowanych bloków na stanowisku po pszenicy ozimej. Badania przeprowadzono na glebie o składzie mechanicznym gliny piaszczystej i zróżnicowanej zawartości podstawowych makroelementów w zależności od roku badań (tab. 1).

Tabela 1

Table 1

Analiza gleby (lata 2016 - 2018)

Soil analysis (years 2016 - 2018)

\begin{tabular}{|c|c|c|c|c|c|c|c|c|c|}
\hline \multirow{2}{*}{$\begin{array}{l}\text { Rok } \\
\text { Year }\end{array}$} & \multirow{2}{*}{$\begin{array}{l}\mathrm{pH} \text { w } \mathrm{KCl} \\
\mathrm{pH} \text { in } \mathrm{KCl}\end{array}$} & \multicolumn{6}{|c|}{$\begin{array}{c}\mathrm{mg} w 100 \mathrm{~g} \text { gleby } \\
\mathrm{mg} \text { in } 100 \mathrm{~g} \text { soil }\end{array}$} & \multirow{2}{*}{$\begin{array}{c}\text { Próchnica } \\
\text { organic } \\
\text { matter } \\
{[\%]}\end{array}$} & \multirow{2}{*}{$\begin{array}{c}\text { Kategoria } \\
\text { agronomiczna } \\
\text { agronomic } \\
\text { category }\end{array}$} \\
\hline & & & ${ }_{2} \mathrm{O}_{5}$ & & $\mathrm{~K}_{2} \mathrm{O}$ & & $\mathrm{MgO}$ & & \\
\hline 2016 & 5,9 & 18,6 & $\begin{array}{l}\text { wysoka } \\
\text { high }\end{array}$ & 16,0 & $\begin{array}{l}\text { wysoka } \\
\text { high }\end{array}$ & 6,1 & $\begin{array}{l}\text { wysoka } \\
\text { high }\end{array}$ & 2,3 & $\begin{array}{c}\text { glina } \\
\text { piaszczysta } \\
\text { sandy loam }\end{array}$ \\
\hline 2017 & 5,3 & 12,8 & $\begin{array}{l}\text { średnia } \\
\text { medium }\end{array}$ & 7,0 & $\begin{array}{c}\text { niska } \\
\text { low }\end{array}$ & 3,0 & $\begin{array}{c}\text { niska } \\
\text { low }\end{array}$ & 1,6 & $\begin{array}{l}\text { glina } \\
\text { piaszczysta } \\
\text { sandy loam }\end{array}$ \\
\hline 2018 & 5,5 & 20,1 & $\begin{array}{c}\text { bardzo } \\
\text { wysoka } \\
\text { very high }\end{array}$ & 13,0 & $\begin{array}{l}\text { średnia } \\
\text { medium }\end{array}$ & 3,9 & $\begin{array}{c}\text { niska } \\
\text { low }\end{array}$ & 1,6 & $\begin{array}{l}\text { glina } \\
\text { piaszczysta } \\
\text { sandy loam }\end{array}$ \\
\hline
\end{tabular}

Po zbiorze pszenicy ozimej, w sierpniu wysiewano jako przedplon gorczycę białą $\left(25 \mathrm{~kg} \cdot \mathrm{ha}^{-1}\right)$ $\mathrm{z}$ dodatkiem mocznika w dawce $23 \mathrm{~kg} \mathrm{~N} \cdot \mathrm{ha}^{-1}$. Orkę zimową wykonywano na przełomie października i listopada. Na początku kwietnia wykonywano kultywatorowanie gleby. W połowie kwietnia wysiewano wieloskładnikowy nawóz mineralny Yara Mila 14-14-21 w ilości $700 \mathrm{~kg} \cdot \mathrm{ha}^{-1}$, który następnie mieszano $\mathrm{z}$ glebą poprzez 2-krotne kultywatorowanie. Nawozy Micro 1 B i Micro $1 \mathrm{~K}$ wysiewano rzędowo w III dekadzie kwietnia bezpośrednio przed sadzeniem bulw ziemniaka na wyznaczonych poletkach. Po około 20-25 dniach po sadzeniu wykonywano zabieg obsypywania z ostatecznym profilowaniem redliny. Następnie aplikowano herbicyd Plateen 41,5 WG w dawce $2,0 \mathrm{~kg} \cdot \mathrm{ha}^{-1}$. Kolejny zabieg przeciwko zachwaszczeniu wykonywano, gdy rośliny ziemniaka były w fazie zwierania rzędów (BBCH 31-35), stosując herbicyd Titus 25 WG w dawce $60 \mathrm{~g} \cdot \mathrm{ha}^{-1}$. W trakcie wegetacji, w zależności od presji infekcyjnej, prowadzono ochronę przed zarazą ziemniaka i stonką ziemniaczaną (tab. 2).

W trakcie badań prowadzono obserwacje warunków pogodowych (ilość opadów i średnie dobowe temperatury powietrza) na podstawie stacji meteorologicznej w Boninie (rys. 1, fig. 1).

Lata badań prowadzonych na poletkach w Boninie charakteryzowały się zmiennymi warunkami meteorologicznymi. Rok 2016 charakteryzował się znacznie mniejszymi opadami w miesiącach kwiecień - czerwiec i wyższymi w lipcu i sierpniu w porównaniu do wielolecia 
Wykaz środków ochrony roślin stosowanych w doświadczeniu w latach 2016-2018

List of pesticides used in experiment in the years 2016-2018

\begin{tabular}{|c|c|c|c|}
\hline $\begin{array}{l}\text { Środek ochrony roślin } \\
\text { plant protection product }\end{array}$ & 2016 & 2017 & 2018 \\
\hline $\begin{array}{l}\text { Herbicydy } \\
\text { Herbicides }\end{array}$ & $\begin{array}{c}\text { Plateen } 41,5 \mathrm{WG} \\
(2,0 \mathrm{~kg}) \\
\text { Titus } 25 \mathrm{WG}(60 \mathrm{~g})^{*}\end{array}$ & $\begin{array}{l}\text { Plateen } 41,5 \mathrm{WG}(2,0 \mathrm{~kg}) \\
\text { Titus } 25 \mathrm{WG}(60 \mathrm{~g})\end{array}$ & $\begin{array}{c}\text { Plateen } 41,5 \mathrm{WG} \\
\quad(2,0 \mathrm{~kg}) \\
\text { Titus } 25 \mathrm{WG}(60 \mathrm{~g})\end{array}$ \\
\hline $\begin{array}{l}\text { Insektycydy } \\
\text { Insecticides }\end{array}$ & $\begin{array}{l}\text { SpinTor } 240 \text { SC }(0,151) \\
\text { Actara } 25 \text { WG }(80 \mathrm{~g}) \\
\text { Nomolt } 150 \mathrm{SC}(0,25 \mathrm{l})\end{array}$ & Actara 25 WG $(80 \mathrm{~g})$ & Actara $25 \mathrm{WG}(80 \mathrm{~g})$ \\
\hline $\begin{array}{l}\text { Fungicydy } \\
\text { Fungicides }\end{array}$ & $\begin{array}{c}\text { Infinito } 687,5 \mathrm{SC}(1,61) \\
\text { Pyton Consento } 450 \mathrm{SC}(2,01) \\
\text { Infinito } 687,5 \mathrm{SC}(1,61) \\
\text { Infinito } 687,5 \mathrm{SC}(1,61) \\
\text { Quantum } 69 \mathrm{WG} \\
(2,0 \mathrm{~kg}) \\
\text { Curzate Top } 72,5 \mathrm{WG}(2,0 \mathrm{~kg}) \\
\text { Dithane NeoTec } 75 \mathrm{WG}(2,0 \mathrm{~kg}) \\
\text { Altima } 500 \mathrm{SC}(0,41)\end{array}$ & $\begin{array}{c}\text { Infinito 687,5 SC (1,61) } \\
\text { Infinito 687,5 SC (1,61) } \\
\text { Orvego 525 SC }(0,81) \\
\text { Revus 250 SC }(0,61) \\
\text { Drum 45 WG+Ranman Top 160 SC }(0,2 \mathrm{~kg}+0,51) \\
\text { Drum 45 WG+Ranman Top 160 SC }(0,2 \mathrm{~kg}+0,51) \\
\text { Ranman Top 160 SC }(0,51) \\
\text { Banjo Forte 400 SC (08 1) }\end{array}$ & $\begin{array}{c}\text { Infinito } 687,5 \mathrm{SC} \\
(1,61) \\
\text { Infinito } 687,5 \mathrm{SC} \\
(1,61) \\
\text { Pyton Consento } \\
\text { 450 SC }(2,01) \\
\text { Pyton Consento } \\
\text { 450 SC }(2,01) \\
\text { Ranman Top } 160 \mathrm{SC}(0,51)\end{array}$ \\
\hline
\end{tabular}

\footnotetext{
*w nawiasach podano dawké środka zastosowana na 1 hektar

in parentheses dose per hectare is given
}

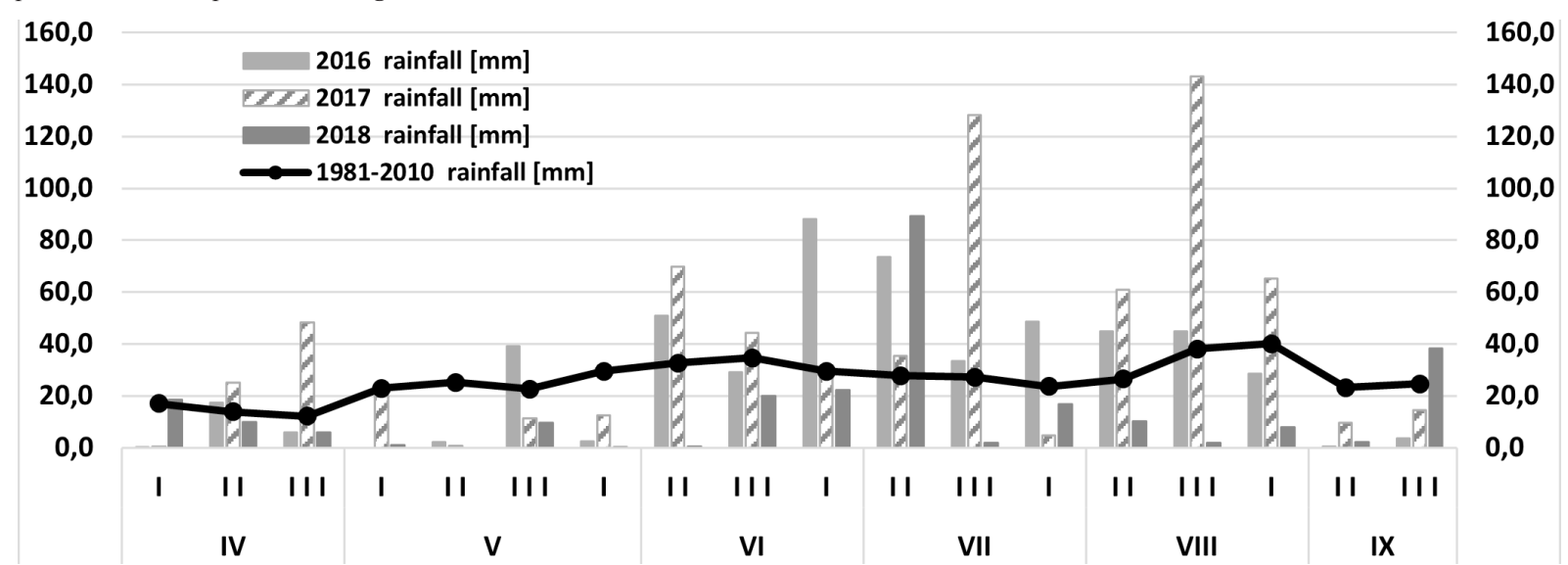

Rys. 1 Sumy opadów w latach 2016-2018 w porównaniu do wielolecia (1981-2010).

Fig. 1 Rainfall in the period 2016-2018 compared to the multi-year period (1981-2010).

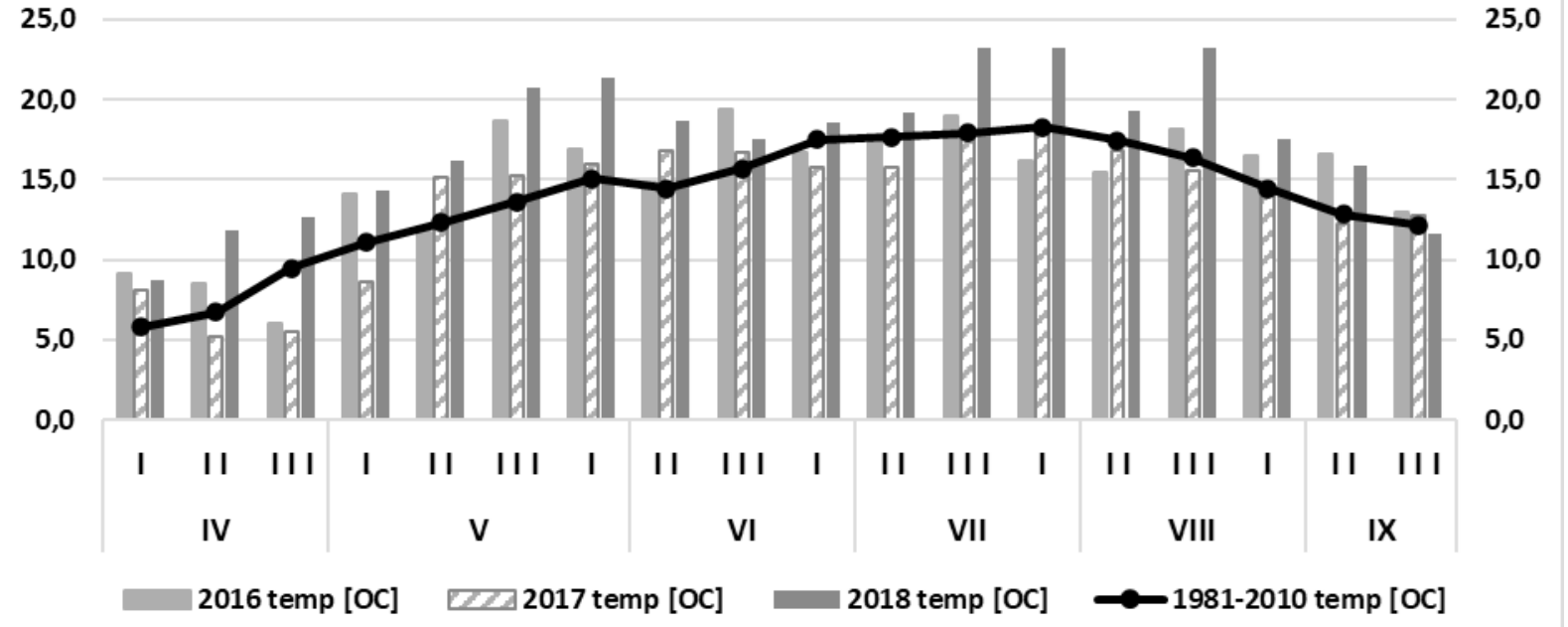

Rys. 2 Średnie dobowe temperatury powietrza w latach 2016-2018 w porównaniu do wielolecia (1981-2010).

Fig. 2 Average daily air temperatures in the period 2016-2018 compared to the multi-year (1981-2010). 
Rok 2017 był rokiem o największej ilości opadów, ale także w porównaniu do średniej ilości opadów za wielolecie (1981 - 2010). Rok 2018 był rokiem suchym, w którym tylko w lipcu ilość opadów przekraczała średnią za wielolecie, w pozostałych miesiącach była znacznie mniejsza.

W okresie prowadzenia badań mniejsze średnie dobowe temperatury powietrza odnotowano w roku 2017. W roku 2018 odnotowano największe temperatury powietrza również $\mathrm{w}$ porównaniu do średniej wieloletniej (rys. 2, fig. 2).

Trzy tygodnie przed zbiorem wykonywano zabieg niszczenia naci metodą mechaniczno-chemiczną, w której po uprzednim rozbiciu łęcin zatosowano Reglone 200 SL w dawce 3,0-4,0 1·ha ${ }^{-1}$. Zbiór przeprowadzano w III dekadzie września. Zebrane ze środkowej redliny z każdego poletka bulwy poddano ocenie:

- plonu ogólnego,

- strukturę plonu handlowego i plon bulw dużych (z kolejnych 10 roślin ze środkowej redliny),

- ciemnienie miąższu surowego.

Tydzień po zbiorze ocenie poddano 10 bulw średniej wielkości, krojąc je wzdłuż osi wierzchołek-stolon i układając je na białej bibule. Po 4 godzinach od momentu przekrojenia wykonano ocenę przy pomocy skali 9-stopniowej, gdzie 9 oznacza barwę nie zmienioną, a 1 ciemnienie najsilniejsze.

- ocenę zawartości skrobi. Ocenę wykonywano cztery tygodnie po zbiorze (dwie próby z każdego poletka po około $2 \mathrm{~kg}$ bulw średniej wielkości) na wadze Reihmana. Dla każdej próby wykonywano 2 pomiary, a za wyniki przyjmowano średnią. Jeśli różnica pomiędzy pomiarami wynosiła więcej niż $0,5 \%$ pomiary powtarzano.

Istotność różnic uzyskanych wyników testowano testem Tukey'a na poziomie istotności $\alpha=0,05$ przy wykorzystaniu programu statystycznego ARM 2020.

\section{Wyniki \\ Plon bulw}

Największy ogólny plony bulw po zastosowaniu badanych wariantów nawożenia uzyskano w roku 2016, plony w pozostałych latach oceny były istotnie mniejsze (tab. 3).

Tabela 3

Table 3

Ogólny plon bulw (t·ha-1) w zależności od roku badań i wariantu nawożenia

The total tuber yield $\left(t \cdot \mathrm{ha}^{-1}\right)$ depending on the year of assessment and the variant of fertilization

\begin{tabular}{|c|c|c|c|c|c|c|}
\hline \multirow{2}{*}{$\begin{array}{l}\text { Rok } \\
\text { Year }\end{array}$} & \multicolumn{5}{|c|}{ Kombinacja Variant } & \multirow{2}{*}{$\begin{array}{l}\text { Średnio } \\
\text { Average }\end{array}$} \\
\hline & $\mathrm{MB}-1$ & $\mathrm{MK}-1$ & NM & $\mathrm{MB}-1+\mathrm{NM}$ & $\mathrm{MK}-1+\mathrm{NM}$ & \\
\hline 2016 & 45,20 & 57,38 & 63,28 & 59,00 & 69,40 & 58,85 \\
\hline 2017 & 38,58 & 37,63 & 55,35 & 55,38 & 56,48 & 48,68 \\
\hline 2018 & 44,45 & 47,55 & 54,73 & 56,35 & 55,25 & 51,67 \\
\hline $\begin{array}{l}\text { Średnio Ave- } \\
\text { rage }\end{array}$ & 42,74 & 47,52 & 57,78 & 56,91 & 60,38 & \\
\hline \multicolumn{7}{|c|}{$\begin{array}{l}\text { NIR }(0,05) / L S D_{(0,05)} \text { dla/for: } \\
\text { kombinacji/variants }=6,014 ; \\
\text { lat/years }=3,971 ; \\
\text { kombinacje } x \text { lata/variants } x \text { years }=10,417 \\
\text { lata } x \text { kombinacjelyears } x \text { variants }=8,880\end{array}$} \\
\hline
\end{tabular}

Spośród ocenianych wariantów nawożenia największy plon ogólny bulw stwierdzono po zastosowaniu podstawowego nawożenia mineralnego $\mathrm{z}$ dodatkiem nawozu Micro $1 \mathrm{~K}(\mathrm{MK}-1+$ NM).

Podobnie jak w przypadku plonu ogólnego, największy plon bulw handlowych (o średnicy powyżej $30 \mathrm{~mm}$ ) stwierdzono $\mathrm{w}$ roku 2016 (tab. 4). Plony w pozostałych latach oceny były istotnie mniejsze. Największe plony uzyskano przy wariancie nawożenia MK - $1+$ NM.

Największy plon bulw dużych (o średnicy powyżej $55 \mathrm{~mm}$ ), przydatnych do przerobu na frytki i chipsy uzyskano z kombinacji, na której zastosowano nawożenie MK - 1 + NM (tab. 5). Plon był zróżnicowany w zależności od wariantu nawożenia oraz roku oceny. Największy udział tej frakcji w plonie ogólnym stwierdzono w roku 2017 i wynosił on od 81,4\% na kombinacji MB - 1 do 97,2\% MB $-1+$ NM. Pomimo zróżnicowanych warunków meteorologicznych stwierdzono korzystny wpływ badanych wariantów doświadczenia na udział frakcji bulw do przetwórstwa. Średnio w latach $2016-$ 2018 udział bulw dużych w plonie ogólnym wynosił od $62,8 \%$ (wariant MB - 1) do 80,7\% (wariant MK $-1+\mathrm{NM})$. 
Plon handlowy (tha- $\left.{ }^{-1}\right)$ w zależności od roku badań i wariantu nawożenia

The marketable yield $\left(\mathrm{tha}^{-1}\right)$ depending on the year of assessment and the variant of fertilization

\begin{tabular}{ccccccc}
\hline \multirow{2}{*}{$\begin{array}{c}\text { Rok } \\
\text { Year }\end{array}$} & \multicolumn{3}{c}{$\begin{array}{c}\text { Kombinacja } \\
\text { Variant }\end{array}$} \\
\cline { 2 - 6 } & $\mathrm{MB}-1$ & $\mathrm{MK}-1$ & $\mathrm{NM}$ & $\mathrm{MB}-1+\mathrm{NM}$ & $\mathrm{MK}-1+\mathrm{NM}$ & $\begin{array}{c}\text { Średnio } \\
\text { Average }\end{array}$ \\
\hline 2016 & 43,48 & 55,53 & 62,23 & 55,63 & 67,93 & 56,96 \\
2017 & 38,58 & 37,40 & 55,35 & 55,38 & 56,48 & 48,64 \\
2018 & 41,48 & 46,30 & 52,80 & 54,95 & 52,68 & 49,64 \\
\hline Średnio & 41,18 & 46,41 & 56,79 & 55,32 & 59,03 & \\
Average & & & & &
\end{tabular}

NIR $(0.05) / L S D_{(0.05)}$ dla/for: kombinacji/variants $=5,912$;

lat years $=3,903$;

kombinacje $x$ lata/variants $x$ years $=10,239$;

lata $x$ kombinacjelyears $x$ variants $=8,728$

Plon bulw dużych (thha $\left.{ }^{-1}\right)$ z zależności od roku oceny i wariantu nawożenia

Table 5

The yield of large tubers $\left(t \cdot \mathrm{ha}^{-1}\right)$ depending on the year of assessment and the variant of fertilization

\begin{tabular}{|c|c|c|c|c|c|c|}
\hline \multirow{2}{*}{$\begin{array}{l}\text { Rok } \\
\text { Year }\end{array}$} & \multicolumn{5}{|c|}{$\begin{array}{c}\text { Kombinacja } \\
\text { Variant }\end{array}$} & \multirow{2}{*}{$\begin{array}{l}\text { Średnio } \\
\text { Average }\end{array}$} \\
\hline & $\mathrm{MB}-1$ & $\mathrm{MK}-1$ & $\mathrm{NM}$ & $\mathrm{MB}-1+\mathrm{NM}$ & $\mathrm{MK}-1+\mathrm{NM}$ & \\
\hline 2016 & 29,68 & 42,20 & 50,80 & 30,43 & 54,08 & 41,44 \\
\hline 2017 & 31,40 & 32,08 & 46,65 & 53,83 & 54,25 & 43,64 \\
\hline 2018 & 19,45 & 21,73 & 35,05 & 39,10 & 37,90 & 30,65 \\
\hline $\begin{array}{l}\text { Średnio } \\
\text { Average }\end{array}$ & 26,84 & 32,00 & 44,17 & 41,12 & 48,74 & \\
\hline
\end{tabular}

$N I R_{(0,05)} / L S D_{(0,05)}$ dla/for: kombinacji/variants $=5,469$

lat/years $=3,611$;

kombinacje $x$ lata/variants $x$ years $=9,472$;

lata $x$ kombinacje/years $x$ variants $=8,074$

\section{Skrobia}

W ocenie zawartości skrobi w bulwach stwierdzono istotne zróżnicowanie pomiędzy badanymi wariantami nawożenia (tab. 6). Największą zawartość skrobi uzyskano dla wariantu MB
- 1 oraz wariantu nawożenia podstawowego NM. Stwierdzono także istotne różnice w zawartości skrobi pomiędzy latami oceny, której największą zawartość w bulwach odnotowano w roku 2017.

Procent skrobi w zależności od roku oceny i wariantu nawożenia

Percent of starch depending on the year of assessment and the variant of fertilization

\begin{tabular}{|c|c|c|c|c|c|c|}
\hline \multirow{2}{*}{$\begin{array}{l}\text { Rok } \\
\text { Year }\end{array}$} & \multicolumn{5}{|c|}{$\begin{array}{l}\text { Kombinacja } \\
\text { Variant }\end{array}$} & \multirow{2}{*}{$\begin{array}{l}\text { Średnio } \\
\text { Average }\end{array}$} \\
\hline & $\mathrm{MB}-1$ & $\mathrm{MK}-1$ & NM & $\mathrm{MB}-1+\mathrm{NM}$ & $\mathrm{MK}-1+\mathrm{NM}$ & \\
\hline 2016 & 15,563 & 15,400 & 14,313 & 14,363 & 15,213 & 14,970 \\
\hline 2017 & 17,100 & 16,775 & 17,050 & 15,750 & 16,175 & 16,570 \\
\hline 2018 & 15,513 & 15,100 & 16,125 & 15,788 & 15,550 & 15,615 \\
\hline $\begin{array}{l}\text { Średnio } \\
\text { Average }\end{array}$ & 16,058 & 15,758 & 15,829 & 15,300 & 15,646 & \\
\hline
\end{tabular}

NIR $20.0 S D_{(0.05)}$ dla/for: kombinacji/variants $=0,669$;

lat/years $=0,442$;

kombinacje $x$ lata/variants $x$ years $=1,159$;

lata $x$ kombinacjelyears $x$ variants $=0,988$ 


\section{Ciemnienie enzymatyczne}

Analizując ciemnienie enzymatyczne bulw nie stwierdzono istotnych różnic pomiędzy badanymi wariantami doświadczenia (tab.7). Istotne zróżnicowanie $\mathrm{w}$ ocenie tego parametru odnotowano natomiast pomiędzy latami oceny. Tylko w roku 2018, który charakteryzował się najmniejszą ilością opadów, a także największymi temperaturami nie stwierdzono żadnych oznak zmian zabarwienia miąższu bulw po 4 godzinach od przekrojenia.

Ciemnienie enzymatyczne bulw w zależności od roku oceny i wariantu nawożenia

Tuber enzymatic darkening depending on the year of assessment and the variant of fertilization

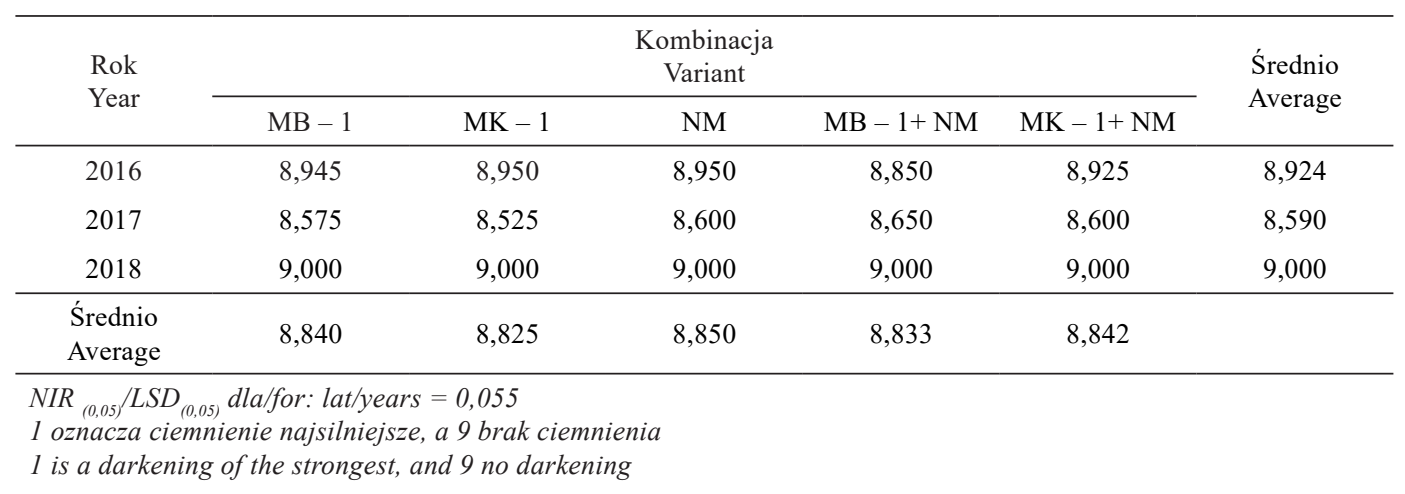

\section{Dyskusja}

Na rozwój roślin i ich plonowanie znaczący wpływ miał nie tylko rodzaj gleby i nawożenie, ale także przebieg pogody $\mathrm{w}$ okresie wegetacji (rys. 1 i 2). Według Chmury i innych (2013) plon ziemniaków odmian średnio późnych (do tej grupy należy uprawiana w doświadczeniu odmiana Jelly) oraz późnych jest uzależniony od sumy opadów. Według ich doniesień niższe sumy opadów w pierwszym okresie wegetacji (maj-czerwiec) i wyższe $\mathrm{w}$ miesiącach lipiec-sierpień zapewniają wysokie plony bulw. Taką sytuację $\mathrm{w}$ przeprowadzonym badaniu stwierdzono w roku 2016, w którym suma opadów za miesiące kwiecień-czerwiec była niższa, a wyższe sumy opadów stwierdzono w drugim okresie wegetacji. W roku 2017 wysokie ilości opadów nie sprzyjały gromadzeniu plonu. Rokiem o najmniej korzystnych warunkach dla rozwoju roślin ziemniaka i gromadzenia plonu bulw potomnych w badanym okresie był rok 2018. Charakteryzował się on dużym niedoborem opadów oraz wysokimi temperaturami powietrza. Jak uważa Borówczak (2012) niskie ilości opadów w okresie zawiązywania bulw i gromadzenia plonu mają wpływ nie tylko na jego wielkość, ale także na przydatność do przerobu przemysłowego. W przeprowadzonym doświadczeniu w roku 2018 odnotowano najmniejszy udział bulw dużych (średnica powyżej $55 \mathrm{~mm}$ ) w każdej z badanych kombinacji.

Zastosowanie, jako uzupełnienie nawożenia podstawowego (Yara Mila 14-14-21 w ilości
$700 \mathrm{~kg} \cdot \mathrm{ha}^{-1}$ ), nawozów Micro $1 \mathrm{~B}$ i Micro $1 \mathrm{~K}$ miało korzystny wpływ na wielkość plonu ogólnego, plonu handlowego oraz bulw dużych przeznaczonych do przerobu przemysłowego. Najwyższy przyrost plonu bulw dużych uzyskano w latach 2017 i 2016 po zastosowaniu nawozu Micro $1 \mathrm{~K}$, wynosił on $5,7 \mathrm{tha}^{-1}$ dla plonu handlowego i ponad $6,1 \mathrm{t}$. ha $^{-1}$ dla plonu ogólnego bulw oraz ponad 7 tha ${ }^{-1}$, niż w roku 2018, w porównaniu $\mathrm{z}$ innymi wariantami nawożenia.

Ten korzystny wpływ na wielkość plonu po zastosowaniu nawozu Micro $1 \mathrm{~K}$ może być związany z dodatkową zawartością w jego składzie potasu i fosforu. Jak podają Grzebisz i Härdter (2006), Grzebisz (2011) oraz Grześkowiak (2013) ziemniak reaguje wzrostem plonu na zrównoważone nawożenie potasem. Istotną rolę potasu w plonowaniu ziemniaka potwierdzają także badania Stępnia i in. (2005, 2009) oraz Trawczyńskiego (2005).

Skrobia jest jednym $\mathrm{z}$ ważnych produktów wykorzystywanych przez przemysł spożywczy, farmaceutyczny i papierniczy (Sznajder i Tarant, 2002, Dzwonkowski, 2010). Jej znaczenie wzrasta w związku z nowymi perspektywami wykorzystania związanymi z dążeniem do stosowania produktów bezpiecznych dla środowiska. W procesach biotechnologicznych i w przemyśle chemicznym, skrobia jako naturalny, odnawialny i biodegradowalny surowiec coraz częściej zastępuje polimery pochodzenia petrochemicznego (Kołodziejczyk i in., 2013). W przeprowadzonym doświadczeniu stwierdzono istotny korzystny wpływ nawożenia 
na zawartość skrobi w zależności od badanego wariantu doświadczenia, lat oraz współdziałania lat i badanych wariantów doświadczenia. Najwyższą zawartość skrobi stwierdzono dla wariantu MB - 1 i NM w roku 2017. Jak stwierdzają Puła i Skowera (2004) oraz Wojciechowski i in. (2013) do wzrostu skrobi w bulwach przyczyniają się duże ilości opadów w okresie formowania bulw. Wyniki uzyskane w tym doświadczeniu wydają się potwierdzać tę tezę. Kołodziejczyk (2014) uważa, że oprócz ilości opadów na gromadzenie się skrobi istotny wpływ ma także rozkład opadów i temperatury w okresie wegetacji. Wierzbicka (2012) uzupełniając doniesienia o znaczeniu opadów i temperatury stwierdza, że gromadzenie się skrobi może być także zależne od wysokości temperatury w końcowym okresie wegetacji. Zawartość skrobi w bulwach jest także zależna od odmiany (Jabłoński, 2005, Styszko i Kamasa, 2006). Wierzbicka (2011) stwierdza, że zawartość skrobi jest także zależna od długości wegetacji roślin oraz wielkości bulw. Stwierdzenie to potwierdzają Styszko i in. (2001), według których istnieje dodatnia korelacja pomiędzy zawartością skrobi a długością okresu wegetacji oraz ujemna z wielkością bulwy i zawartością białka.

Jednym z parametrów określających przydatność bulw do przetwórstwa, a szczególnie na frytki i chipsy jest ciemnienie miąższu. Według Leszczyńskiego (2000) następuje ono w wyniku utleniania tyrozyny i kwasu chlorogenowego w obecności enzymu oksydazy polifenolowej. Jednak jak uważa Kołodziejczyk (2014) ciemnienie miąższu może być także cechą odmianową, chociaż nie wyklucza, że warunki środowiska mogą odgrywać istotną rolę. Do czynników mających wpływ na ciemnienie Ciećko i in. (2005) zaliczają nawożenie potasem, a jak podkreśla Trawczyński (2012) duży wpływ na ciemnienie bulw może mieć forma zastosowanego nawozu. W przeprowadzonym doświadczeniu nie stwierdzono istotnych różnic w ciemnieniu bulw po zastosowaniu badanych form nawożenia. Różnice zostały jednak zauważone pomiędzy latami badań. Najmniejsze zmiany w ciemnieniu miąższu bulw stwierdzono w roku 2018 charakteryzującym się umiarkowaną ilością opadów i stosunkowo wysokimi temperaturami pod koniec wegetacji. Uzyskane wyniki zdają się potwierdzać doniesienia Sawickiej (2000), Kołodziejczyka i in. (2005) oraz Osowskiego i in. (2017).

\section{Wnioski}

1. Na wielkość uzyskanego plonu bulw decydujący wpływ miał przebieg warunków pogodowych w poszczególnych latach badań.

2. Zastosowanie do nawożenia uzupełniającego nawozu Mikro $1 \mathrm{~K}$ korzystnie wpłynęło na wysokość plonu ogólnego, handlowego oraz plonu bulw dużych w porównaniu z nawożeniem mineralnym (NM).

3. Najwyższy przyrost plonu bulw uzyskano w latach 2017 i 2016 po zastosowaniu nawozu Micro $1 \mathrm{~K}$, wynosił on $5,7 \mathrm{tha}^{-1}$ dla plonu handlowego $\mathrm{i}$ ponad $6,1 \mathrm{tha}^{-1}$ dla plonu ogólnego bulw oraz ponad 7 tha $^{-1}$ dla plonu bulw dużych w roku 2018, w porównaniu z innymi wariantami nawożenia.

4. W przeprowadzonym doświadczeniu stwierdzono istotny korzystny wpływ nawożenia na zawartość skrobi w zależności od badanego wariantu doświadczenia, lat oraz współdziałania lat i badanych wariantów doświadczenia. Najwyższą średnią zawartość skrobi w bulwach stwierdzono dla wariantu MB -1 .

5. Na poziom ciemnienia miąższu wpływ miał rozkład opadów i temperatur w okresie wegetacji. Najmniejsze ciemnienie miąższu bulw stwierdzono w roku 2018, który charakteryzował się umiarkowaną ilością opadów i stosunkowo wysokimi temperaturami pod koniec wegetacji.

\section{Literatura}

Borówczak F. (2012). Nawadnianie ziemniaków. [W:] Produkcja i rynek ziemniaka. Red. Nauk. Jacek Chotkowski Wieś Jutra: 205-214.

Brown P.H. (2004). Principles of micronutrient use. IFA International Symposium on Micronutrients, 23 - 25 II (2004), New Delhi, India: 12 ss.

Chmura K., Dzieżyc H., Piotrowski M. (2013). Reakcja ziemniaków średnio wczesnych oraz średnio późnych na czynnik wodny w warunkach gleb kompleksów pszennych i żytnich. Infrastruktura i ekologia terenów wiejskich. $\mathrm{Nr}$ 2/I/2013: 103 - 113 .

Ciećko Z., Rogozińska I., Żołnowski A.C., Wyszkowski M. (2005). Oddziaływanie nawożenia potasem przy zróżnicowanych dawkach N i P na cechy kulinarne bulw ziemniaka. Biuletyn IHAR 237/238: 151-159.

Czuba R. (2000). Mikroelementy we współczesnych systemach nawożenia. Zeszyty Problemowe Postępów Nauk Rolniczych, 471: 161 - 169.

Dzwonkowski, W. (2010). Perspektywy produkcji skrobi ziemniaczanej w Polsce. Ziemniak Polski, 4: 3 - 7.

Grzyś E. (2004). Rola i znaczenie mikroelementów w żywieniu roślin. Zeszyty Problemowe Postępów Nauk Rolniczych, 502: 89-99.

Grzebisz W. (2011). Potas - system nawożenia. Wyd. „Prodruk” Poznań, ss 29. 
Grzebisz W., Härdter R. (2006). Kizeryt w systemie nawożenia magnezem i siarką. [W:] ESTA ${ }^{\circledR}$ Kizeryt naturalny siarczan magnezu. $\mathrm{K}+\mathrm{S}$ KALI GmbH, Agricultural Advisory Departament: 61-107.

Grześkowiak A. (2013). Vademecum nawożenia czyli zbiór podstawowych, praktycznych informacji o nawożeniu. Grupa Azoty SA: 16-40.

Imas P., Magen H. (2004). Chloride an essential micronutrient in crop management. IFA International Symposium on Micronutrients, 23 - 25 II (2004), New Delhi, India: 14 ss.

Jabłoński, K. (2005). Wpływ nawożenia azotowego na plon i jakość bulw nowych odmian ziemniaka skrobiowego. Biuletyn IHAR 237/238, 143-149.

Kołodziejczyk M. (2014). Wpływ warunków opadowotermicznych na skład chemiczny oraz wybrane parametry jakości bulw średnio późnych i późnych odmian ziemniaka jadalnego. Annales Uniwersitatis Mariae Curie-Skłodowska Lublin VOL. LXIX (3) SECTIO E: 2-10.

Kołodziejczyk M., Szmigiel A., Marks N., Krzysztofik B. (2005). Oddziaływanie rodzaju nawożenia i typu gleby na ciemnienie miąższu bulw średnio wczesnych odmian ziemniaka. Pam. Puł. 139, 65-74.

Kołodziejczyk M., Szmigiel A., Kulig B., Oleksy A., Lepiarczyk A. (2013). Ocena plonowania, składu chemicznego i jakości bulw wybranych odmian ziemniaka skrobiowego. Inżynieria Rolnicza 2013 Z.3 (146) T.2: 123 - 130.

Leszczyński W. (2000). Jakość ziemniaka konsumpcyjnego. Żywność, 4 (25) Supl.: 5-27.

Osowski J., Erlichowski T., Urbanowicz J. (2017). Wpływ nawożenia potasem, magnezem i siarką na plonowanie, ciemnienie bulw surowych oraz występowanie alternariozy i ospowatości bulw ziemniaka. Fragm. Agron. 34 (1): 49-59.

Puła J., Skowera B. (2004). Zmienność cech jakościowych bulw ziemniaka odmiany Mila uprawianego na glebie lekkiej w zależności od warunków pogodowych. Acta Agrophys. 3 (2): 359-366.Sawicka B. (2000). Wpływ technologii produkcji na jakość bulw ziemniaka. Pam. Puł. 120, 391-401.

Stępień W., Rutkowska B., Szulc W. (2009) Wpływ stosowania różnych nawozów potasowych na plony i jakość roślin. Zesz. Probl. Post. Nauk Rol. 538: 251-256.
Stępień W., Mercik S., Sosulski T. (2005). Wpływ formy nawozu potasowego i sposobu nawożenia na plon i jakość roślin. Nawozy i nawożenie 3 (24): 401-407.

Styszko, L., Kamasa, J. (2006). Relacje pomiędzy odpornością odmian ziemniaka na patogeny a plonem skrobi w latach o różnym poziomie plonowania. Progres in Plant Protection/Postępy w Ochronie Roślin, 46 (2), 512-516.

Styszko, L., Modzelewski, T., Kamasa, J., Majewski, A. (2001). Relacje pomiędzy cechami morfologii bulw ziemniaka a zawartością skrobi w bulwach i jej plonem. Zeszyty Naukowe AR Wrocław, ser. Rolnictwo, 415, 283-293.

Sznajder M., Tarant S. (2002). Ekonomika i rynek. [W:] Ekonomika i technologia produkcji ziemniaków skrobiowych. Red. Nauk. Jacek Chotkowski Wieś Jutra: 7-15.

Szewczuk C. (2009). Wpływ dokarmiania dolistnego na plon bulw ziemniaka. Annales UMCS, Agricultura, 64 (1): $7-12$.

Trawczyński C. (2005). Wykorzystanie potasu przez ziemniak w warunkach zróżnicowanego nawożenia. Fragmenta Agronomica 85: 591-599.

Trawczyński C. (2012). Przygotowanie stanowiska i nawożenie ziemniaka. [W:] Produkcja i rynek ziemniaka. Red. Nauk. Jacek Chotkowski Wieś Jutra: 183-197.

Trawczyński C., Prokop W. (2016). Plon i jakość bulw ziemniaka $\mathrm{w}$ zależności od zastosowanego nawożenia z wykorzystaniem doglebowych i dolistnych wieloskładnikowych preparatów nawozowych. Polish Journal of Agronomy 2016, 24, 23 - 29.

Wierzbicka, A. (2011). Wybrane cechy jakości bulw ziemniaków uprawianych w systemie ekologicznym w zależności od nawadniania. Journal of Research and Applications in Agricultural Engineering, 56(4), 203-207.

Wierzbicka A., 2012. Wpływ odmiany, nawożenia azotem i terminu zbioru na zawartość suchej masy i skrobi w bulwach ziemniaków wczesnych. Fragm. Agron. 29 (2), 134-142.

Wojciechowski W., Lehmann A., Wacławowicz R. (2013). Reakcja odmian na uproszczenia w zmianowaniu. Fragm. Agron. 30 (4): 181-188.

Zarzecka K. (2006). Uprawa ziemniaka w Polsce warunkująca właściwą jakość plonu. Zeszyty Problemowe Postępów Nauk Rolniczych, 511: 53-72. 